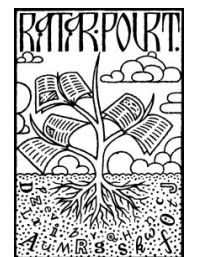

\title{
Chamomile essential oil quality after postharvest separation treatments
}

\author{
Milica Aćimovići ${ }^{*} \cdot$ Biljana Lončar ${ }^{2}$ - Biljana Kiprovski $i^{1}$ Jovana Stanković Jeremić ${ }^{3}$. \\ Marina Todosijević ${ }^{4} \cdot$ Lato Pezo $^{5} \cdot$ Jelena Jeremić $^{2,6}$
}

${ }^{1}$ Institute of Field and Vegetable Crops, Novi Sad, Serbia

2 Faculty of Technology, University of Novi Sad, Serbia

${ }^{3}$ Institute of Chemistry, Technology and Metallurgy, University of Belgrade, Serbia

${ }^{4}$ Faculty of Chemistry, University of Belgrade, Serbia

${ }^{5}$ Institute of General and Physical Chemistry, University of Belgrade, Serbia

${ }^{6}$ Euro Prima doo, Novi Sad, Serbia

\begin{abstract}
Summary: Ecological conditions of the growing areas, growing practices as well as harvest and postharvest processing influence the yield and quality of chamomile. The aim of this research was to determine the influence of chamomile separation methods, as postharvest treatments, on the essential oil quality and content, with a view to improve current primary processing of this valuable medicinal plant. In order to explain the structure of laboratory data that would give deeper assessment of similarities among various samples of chamomile essential oil, PCA was employed. Tested results showed that separation of chamomile plant material, as postharvest and pre-drying treatment, had significant influence on the number of identified compounds in the chamomile essential oil. The highest content of individual essential oil compounds had chamomile flowers with short stems, especially a-bisabolol, chamazulene, $Z$-spiroether and $E$ - $\beta$-farnesene. In the essential oil obtained from chamomile flowers with long stems, content of $a$-bisabolol and chamazulene were significantly lower, while $E$ - $\beta$-farnesene and $Z$-spiroether contents were significantly higher. Furthermore, in the essential oil obtained from chamomile plant material without separation, the lowest content of $a$ bisabolol and $Z$-spiroether, and the highest content of $E$ - $\beta$-farnesene were recorded. The correlation analysis was performed to investigate the likeness in the amounts of the active compounds of essential oil from differently processed chamomile samples. All these results indicate the importance of precise and controlled postharvest treatments, since it clearly affects the essential oil quality and content in the primary processing of this valuable medicinal plant.

Key words: essential oil, Matricaria chamomilla, medicinal plants, postharvest, primary processing, separation
\end{abstract}

\section{Introduction}

Chamomile (Matricaria chamomilla L. syn. Chamomilla recutita L.) herbal tea is very popular because of its sweet, grassy, lightly fruity aroma and due to its calming, carminative and spasmolytic properties (Zadeh et al., 2014). It is extensively used in the cosmetic industry: for preparation of skin creams, oils and bath additives, due

Corresponding author:

milica.acimovic@ifvens.ns.ac.rs

Acknowledgement: This research was supported by the Ministry of Education, Science and Technological Development of the Republic of Serbia, gran number: 451-03-9/2021-14/200032 and Interreg - IPA CBC HUSRB 7190374270059 .

Cite this article:

Aćimović M., Lončar B., Kiprovski B., Stanković Jeremić J., Todosijević M., Pezo L., Jeremić J. (2021). Chamomile essential oil quality after postharvest separation treatments. Ratar. Pourt., 58 (2), 72-78. to its effectiveness in treating skin inflammation, atopic dermatitis, peristomal skin problems, etc. It can also be found in mouthwash products, toothpaste, decorative cosmetics and shampoos (Sarkic \& Stappen, 2018).

On the market, chamomile is usually sold as dry flowers (Chamomillae flos) and essential oil (Chamomillae aetheroleum). Dried chamomile flowers are bought by tea companies, producers of herbal extracts and health food shops, while pharmaceutical, cosmetic and aromatherapy companies are the most common buyers of its essential oil. In spite of the global market growth, the world is facing large discrepancy between demand and supply of high-quality flowers and essential oil of chamomile (Upadhyay et al., 2016).

Despite the fact that their production area is comparably small worldwide, chamomile belongs to the group of the minor, but highly valuable crops (Karkanis et al., 2018). It is usually produced in countries with low labor costs and exported to industrialized countries (Arslan et al., 2019). Prices are largely regulated by the global supply and demand. Quality is one of the main criteria during price formation. 
Ecological conditions of the growing areas (Letchamo, 1996; Gosztola et al., 2010), as well as growing practices (Ghasemi et al., 2016; Upadhyay et al., 2016) influence the yield and quality of chamomile. However, the major factor causing differences in the quality may be the time between harvest and distillation (Bucko \& Salamon, 2007).

Since mechanically gathered, fresh chamomile flowers have a very high respiration rate, the reason of which there is a need for intensive and immediate postharvest treatment, including ventilation, cooling or drying (Bottcher et al., 2001). Pre-drying separation is usually performed by a drum separator, which divides the material into two fractions that are dried separately: (1) chamomile flowers with stem length up to $30 \mathrm{~mm}$, and (2) long stems with a small quantity of flowers, mixed with weed. Separate drying of first- and secondclass harvest material enables better quality and higher dryer output. Pre-dying processing, primary separation and classification, can be performed by different procedures and machines (Oztekin \& Martinov, 2007). Additionally, herbal material dried in a bulk immediately after the harvest, without process of separation, is regarded as a final product, as well (Szabo et al., 2010).

In Serbia, chamomile is grown as a field crop; the annual amount exported is over 300,000 t of dried flowers (2016) with the tendency to grow. Apart from domestic varieties "Banatska" and "Tetraploidna", there are others being grown as well exclusively for export to Germany, "Mabamille", "Zloty Lan", "Lutea" and "Manzana" (Acimovic et al., 2018; Acimovic et al., 2021).

The aim of this research was to determine the influence of chamomile separation methods, as postharvest treatments, on the essential oil quality and content, with a view to improve current primary processing of this valuable medicinal plant.

\section{Material and methods}

\section{Plant material}

German chamomile (Matricaria chamomilla L.) variety 'Mabamille' was cultivated at plantation field of commercial tea company, MACVAL GROUP, located in

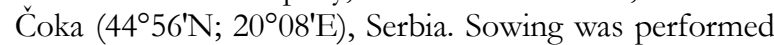
during September 2019, and the harvest was done during May 2020.

\section{Postharvest pre-dying treatments}

One part of the harvested material was dried immediately after the harvest, without further separation, while the other went through the process of pre-drying separation in a drum separator. Two fractions were obtained during this process: flowers with short stems (first class) and raw material with long stems with and small quantity of flowers (second class). All obtained fractions were dried in a conveyor dryer with five drying belts at $40{ }^{\circ} \mathrm{C}$. The scheme in Figure 1 shows postharvest pre-drying treatments of chamomile.

\section{Essential oil extraction and analysis}

Dried chamomile samples were subjected to hydrodistillation using an all-glass Clevenger-type apparatus to extract essential oil according to the method outlined by the Ph. Eur. 8.0 (2013). In order to extract the essential oil, $100 \mathrm{~g}$ of analyzed plant material was placed in a $1000 \mathrm{ml}$ conical flask with $300 \mathrm{ml}$ of distilled water and connected to the Clevenger apparatus. The steam in combination with the essential oils was distilled into a graduated cylinder for $4 \mathrm{~h}$ and then separated from the aqueous layer. Collected oil was kept refrigerated until required for further analysis.

Gas chromatographic-mass spectrometric analysis was performed using an Agilent 6890 gas chromatograph coupled with an Agilent 5973 Network mass selective detector (MSD) (both Agilent, Santa Clara, USA), in positive ion-electron impact (EI) mode. The separation was effected using Agilent 19091S-433 HP-5MS fused silica capillary column with $30 \mathrm{~m} \times 0.25$ $\mathrm{mm}$ i.d., $0.25 \mu \mathrm{m}$ film thickness. The GC oven temperature was programmed from $60{ }^{\circ} \mathrm{C}$ to $285^{\circ} \mathrm{C}$ at a rate of $3{ }^{\circ} \mathrm{C} / \mathrm{min}$. Helium was used as carrier gas; inlet pressure was $20.3 \mathrm{kPa}$; linear velocity was $1 \mathrm{ml} / \mathrm{min}$ at $210{ }^{\circ} \mathrm{C}$. Injector temperature: $250^{\circ} \mathrm{C}$; injection mode: splitless. MS scan conditions: MS source temperature, $230{ }^{\circ} \mathrm{C}$; MS Quad temperature, $150{ }^{\circ} \mathrm{C}$; energy, $70 \mathrm{eV}$; mass scan range, $40-550$ amu. The identification of components was carried out based on retention index and by comparison with reference spectra (Wiley and NIST databases).

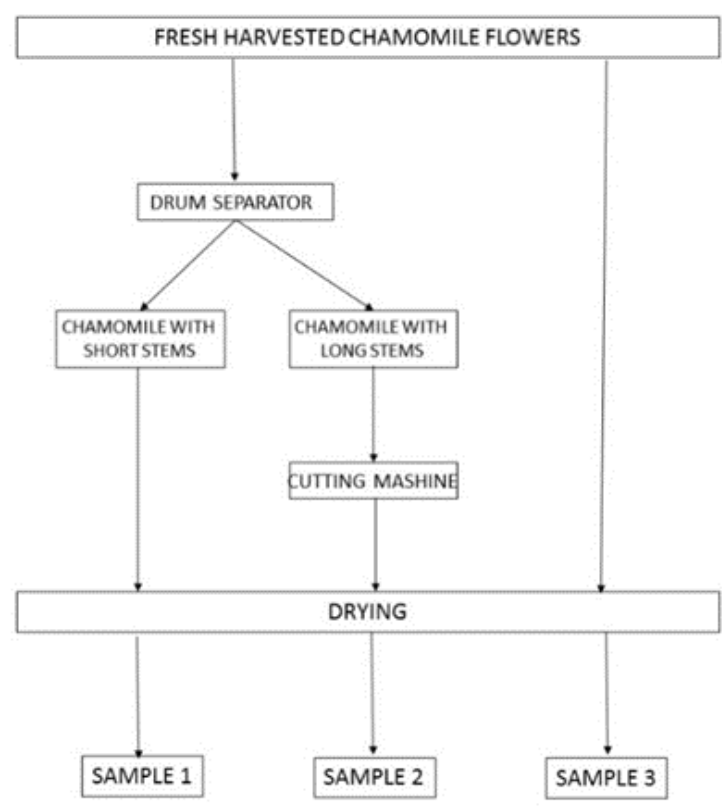

Figure 1. Scheme of the postharvest pre-dying treatments of chamomile raw material 


\section{Statistical analysis}

Principal component analysis (PCA) was done for testing the effect of postharvest pre-drying treatments on chamomile essential oil chemical profile and content. By comprehending the PCA plot of the gathered samples, the perspective trend for a deeper understanding of the essential oil quality profile could be realized. The correlation analysis was performed to investigate the likeness in active compounds content of the various samples. Statistical analysis of the data was performed using the Statistica for Windows 10 software (StatSoft, Inc.). To investigate the visual similarities between different samples, the correlation analysis was performed by the $\mathrm{R}$ software 4.0.3 (64-bit version).

\section{Results and discussion}

As already confirmed (Abbas et al. 2021), drying methods significantly influence the number and content of essential oil identified compounds. However, additional processing could add-up to the existing loss of volatile compounds, due to extensive operations with the material.

The tested results showed that separation of chamomile plant material, as postharvest and pre-drying treatment, had significant influence on the number of identified compounds in the chamomile essential oil (Table 1). Chamomile flowers with long stems had the highest number of identified essential oil compounds (57), followed by chamomile plant material without separation (53) and chamomile flowers with short stems (47).

The highest content of individual essential oil compounds had chamomile flowers with short stems
(Sample 1), especially a-bisabolol (42.9\%), chamazulene (16.0\%), Z-spiroether (11.8\%) and $E$ - $\beta$-farnesene (9.3\%). In the essential oil obtained from chamomile flowers with long stems (Sample 2), content of $a$-Bisabolol and chamazulene were significantly lower $(36.8 \%$ and $12.0 \%$, respectively), while $E$ - $\beta$-farnesene and $Z$-spiroether contents were significantly higher $(19.1 \%$ and $12.3 \%)$. Furthermore, in the essential oil obtained from chamomile plant material without separation (Sample 3), the lowest content of $a$-Bisabolol $(32.2 \%)$ and $Z$ spiroether $(9.3 \%)$, and the highest content of $E$ - $\beta$ farnesene $(24.9 \%)$ were recorded. In addition, Samples 2 and 3 had similar content of chamazulene, contrary to Sample 1 which had 3-4\% higher content of this compound (Table 1).

In order to explain the structure of laboratory data that would give deeper assessment of similarities among various samples of chamomile essential oil, PCA was employed, and the results are presented in the Figure 2. The first two PCs explained 100\% of the total variance in the experimental data. According to results, Sample 1 was characterized by the increased values of $\mathrm{C} 3, \mathrm{C} 5, \mathrm{C} 8$, C30, C40, C42, C44, C45, C48, C55, C59-61, C63 and C65-C69. Sample 2 showed the augmented values of C29, C32, C51 and C53, while sample 3 was indicated by high concentrations of C1, C6, C11, C12, C15, C17, C20 and $\mathrm{C} 21$.

The correlation analysis was performed to investigate the likeness in the amounts of the active compounds of essential oil from differently processed chamomile samples (chamomile flowers with short and long stems and chamomile plant material without separation), and

Table 1. Chamomile essential oil quality. RI - Retention Index; Sample 1 - chamomile flowers with short stems; Sample 2 chamomile flowers with long stems; Sample 3 - chamomile herbal material without separation; NI - Not Identified; nd - not detected. Results marked with different letters in superscript indicate statistically significant difference between mean values $(\mathrm{p}<0.05$, Tukey's HSD test).

\begin{tabular}{|c|c|c|c|c|c|}
\hline No & Compound & RI & Sample 1 & Sample 2 & Sample 3 \\
\hline C1 & Sabinene ${ }^{\mathrm{MT}}$ & 970 & $\operatorname{tr}$ & $0.1 \pm 0.0^{\mathrm{a}}$ & $0.1 \pm 0.0^{\mathrm{a}}$ \\
\hline C2 & E- $\beta$-Ocimene ${ }^{\mathrm{MT}}$ & 1044 & $0.1 \pm 0.0^{\mathrm{a}}$ & $0.1 \pm 0.0^{a}$ & $0.1 \pm 0.0^{a}$ \\
\hline C3 & $\gamma$-Terpinene ${ }^{\mathrm{MT}}$ & 1055 & $0.1 \pm 0.0^{\mathrm{a}}$ & tr & tr \\
\hline $\mathrm{C} 4$ & Artemisiaketone ОМт & 1057 & $0.1 \pm 0.0^{\mathrm{a}}$ & $0.1 \pm 0.0^{\mathrm{a}}$ & $0.1 \pm 0.0^{\mathrm{a}}$ \\
\hline C5 & ArtemisiaalcoholOMT & 1080 & $0.1 \pm 0.0^{\mathrm{a}}$ & nd & nd \\
\hline C6 & $\delta$-Elemene $e^{S T}$ & 1335 & nd & $0.3 \pm 0.0^{\mathrm{a}}$ & $0.4 \pm 0.0^{\mathrm{b}}$ \\
\hline $\mathrm{C} 7$ & NI & 1367 & nd & $0.1 \pm 0.0^{\mathrm{a}}$ & nd \\
\hline C8 & Decanoicacid $\mathrm{O}$ & 1377 & $1.1 \pm 0.1^{\mathrm{a}}$ & nd & nd \\
\hline C9 & $\alpha$-Isocomene $e^{\mathrm{ST}}$ & 1384 & $0.1 \pm 0.0^{\mathrm{a}}$ & $0.1 \pm 0.0^{\mathrm{a}}$ & $0.1 \pm 0.0^{\mathrm{a}}$ \\
\hline C10 & NI & 1390 & nd & $\operatorname{tr}$ & $0.1 \pm 0.0^{\mathrm{a}}$ \\
\hline C11 & E-Caryophyllene $e^{S T}$ & 1417 & $0.2 \pm 0.0^{\mathrm{a}}$ & $0.4 \pm 0.0^{\mathrm{b}}$ & $0.6 \pm 0.1^{\mathrm{c}}$ \\
\hline C12 & $\beta$-Copaene ${ }^{S T}$ & 1427 & nd & $0.2 \pm 0.0^{\mathrm{a}}$ & $0.2 \pm 0.0^{a}$ \\
\hline C13 & NI & 1442 & nd & $0.1 \pm 0.0^{\mathrm{a}}$ & $0.1 \pm 0.0^{\mathrm{a}}$ \\
\hline C14 & NI & 1451 & nd & $0.1 \pm 0.0^{\mathrm{a}}$ & $0.1 \pm 0.0^{\mathrm{a}}$ \\
\hline C15 & E- $\beta$-Farnesene ${ }^{\mathrm{ST}}$ & 1458 & $9.3 \pm 0.7^{\mathrm{a}}$ & $19.1 \pm 1.3^{\mathrm{b}}$ & $24.9 \pm 1.9 c$ \\
\hline C16 & dehydro-SesquicineoleOST & 1469 & $0.2 \pm 0.0^{\mathrm{a}}$ & $0.2 \pm 0.0^{\mathrm{a}}$ & $0.2 \pm 0.0^{\mathrm{a}}$ \\
\hline C17 & Germacrene D ST & 1482 & $2.5 \pm 0.2^{\mathrm{a}}$ & $3.8 \pm 0.4^{b}$ & $5.2 \pm 0.1^{\mathrm{c}}$ \\
\hline C18 & $\beta$-SelineneST & 1485 & $0.1 \pm 0.0^{\mathrm{a}}$ & $0.1 \pm 0.0^{\mathrm{a}}$ & $0.1 \pm 0.0^{\mathrm{a}}$ \\
\hline C19 & NI & 1494 & $0.1 \pm 0.0^{\mathrm{a}}$ & $0.2 \pm 0.0^{\mathrm{b}}$ & $0.2 \pm 0.0^{\mathrm{b}}$ \\
\hline $\mathrm{C} 20$ & Bicyclogermacrene $e^{S T}$ & 1496 & $0.9 \pm 0.1^{b}$ & $0.7 \pm 0.1^{\mathrm{a}}$ & $1.1 \pm 0.1^{c}$ \\
\hline C21 & E,E- $\alpha$-Farnesene ${ }^{S T}$ & 1507 & $0.9 \pm 0.1^{\mathrm{a}}$ & $2.5 \pm 0.2^{\mathrm{b}}$ & $3.2 \pm 0.1^{\mathrm{c}}$ \\
\hline
\end{tabular}




\begin{tabular}{|c|c|c|c|c|c|}
\hline $\mathrm{C} 22$ & $\delta$-Cadinene ${ }^{\mathrm{ST}}$ & 1523 & $0.1 \pm 0.0^{a}$ & $0.1 \pm 0.0^{\mathrm{a}}$ & $0.1 \pm 0.0^{\mathrm{a}}$ \\
\hline $\mathrm{C} 23$ & $\mathrm{NI}$ & 1533 & nd & $0.1 \pm 0.0^{\mathrm{a}}$ & nd \\
\hline $\mathrm{C} 24$ & NI & 1552 & $\operatorname{tr}$ & $0.1 \pm 0.0^{\mathrm{a}}$ & nd \\
\hline $\mathrm{C} 25$ & NI & 1555 & nd & $0.1 \pm 0.0^{\mathrm{a}}$ & nd \\
\hline C26 & NI & 1557 & $0.1 \pm 0.0^{\mathrm{a}}$ & nd & $0.1 \pm 0.0^{\mathrm{a}}$ \\
\hline $\mathrm{C} 27$ & NI & 1561 & $0.1 \pm 0.0^{\mathrm{a}}$ & $0.1 \pm 0.0^{\mathrm{a}}$ & $0.1 \pm 0.0^{a}$ \\
\hline C28 & NI & 1562 & $\operatorname{tr}$ & $0.1 \pm 0.0^{\mathrm{a}}$ & tr \\
\hline $\mathrm{C} 29$ & SpathulenolosT & 1576 & $0.6 \pm 0.1^{\mathrm{ab}}$ & $0.7 \pm 0.1^{b}$ & $0.5 \pm 0.0^{\mathrm{a}}$ \\
\hline $\mathrm{C} 30$ & Caryophyllene oxide OST & 1581 & $0.2 \pm 0.0^{\mathrm{b}}$ & $0.1 \pm 0.0^{\mathrm{a}}$ & $0.1 \pm 0.0^{\mathrm{a}}$ \\
\hline C31 & $\mathrm{NI}$ & 1584 & nd & $0.1 \pm 0.0^{\mathrm{a}}$ & nd \\
\hline C 32 & Salvial-4(14)-en-1-one OST & 1589 & nd & $0.1 \pm 0.0^{\mathrm{a}}$ & $\operatorname{tr}$ \\
\hline C33 & NI & 1597 & nd & $0.1 \pm 0.0^{\mathrm{a}}$ & nd \\
\hline C34 & NI & 1595 & nd & nd & $0.1 \pm 0.0^{\mathrm{a}}$ \\
\hline C35 & NI & 1610 & $0.1 \pm 0.0^{\mathrm{a}}$ & $0.1 \pm 0.0^{\mathrm{a}}$ & $0.1 \pm 0.0^{\mathrm{a}}$ \\
\hline C36 & NI & 1614 & $0.1 \pm 0.0^{\mathrm{a}}$ & $0.1 \pm 0.0^{\mathrm{a}}$ & $0.1 \pm 0.0^{\mathrm{a}}$ \\
\hline C37 & NI & 1628 & $0.1 \pm 0.0^{\mathrm{a}}$ & $0.1 \pm 0.0^{\mathrm{a}}$ & $0.1 \pm 0.0^{\mathrm{a}}$ \\
\hline C38 & NI & 1633 & nd & $0.1 \pm 0.0^{\mathrm{a}}$ & nd \\
\hline C39 & $\mathrm{NI}$ & 1637 & $0.1 \pm 0.0^{\mathrm{a}}$ & nd & $0.1 \pm 0.0^{\mathrm{a}}$ \\
\hline C40 & $\alpha$-Bisabolol oxide B OST & 1655 & $3.6 \pm 0.3 c$ & $2.7 \pm 0.1^{b}$ & $1.8 \pm 0.0^{\mathrm{a}}$ \\
\hline C41 & $\mathrm{NI}$ & 1660 & $0.1 \pm 0.0^{\mathrm{a}}$ & $0.1 \pm 0.0^{\mathrm{a}}$ & nd \\
\hline C42 & $\alpha$-BisabololosT & 1693 & $42.9 \pm 2.8^{\mathrm{b}}$ & $36.8 \pm 2.8^{\mathrm{ab}}$ & $32.2 \pm 2.4$ \\
\hline C43 & $\mathrm{NI}$ & 1710 & $0.1 \pm 0.0^{\mathrm{a}}$ & $0.1 \pm 0.0^{\mathrm{a}}$ & $0.1 \pm 0.0^{\mathrm{a}}$ \\
\hline C44 & ChamazuleneST & 1736 & $16 \pm 2.1^{\mathrm{a}}$ & $12.0 \pm 0.9 \mathrm{a}$ & $13.7 \pm 0.9$ \\
\hline C45 & $\alpha$-Bisabolol oxide A OST & 1749 & $4.4 \pm 0.3^{b}$ & $2.7 \pm 0.2^{\mathrm{a}}$ & $2.2 \pm 0.2^{\mathrm{a}}$ \\
\hline C46 & $\mathrm{NI}$ & 1755 & $0.2 \pm 0.0^{\mathrm{b}}$ & $0.1 \pm 0.0^{\mathrm{a}}$ & $0.2 \pm 0.0^{\mathrm{b}}$ \\
\hline C47 & NI & 1764 & nd & $0.1 \pm 0.0^{\mathrm{a}}$ & tr \\
\hline C48 & Benzylbenzoate $^{\mathrm{O}}$ & 1766 & $0.1 \pm 0.0^{\mathrm{a}}$ & nd & nd \\
\hline C49 & $\mathrm{NI}$ & 1788 & $0.1 \pm 0.0^{\mathrm{a}}$ & $0.1 \pm 0.0^{\mathrm{a}}$ & $0.1 \pm 0.0^{\mathrm{a}}$ \\
\hline C50 & NI & 1842 & $\operatorname{tr}$ & $0.1 \pm 0.0^{\mathrm{a}}$ & tr \\
\hline C51 & Z-SpiroetherD & 1889 & $11.8 \pm 1.1^{\mathrm{b}}$ & $12.3 \pm 0.6^{b}$ & $9.3 \pm 0.4^{\mathrm{a}}$ \\
\hline C52 & $\mathrm{NI}$ & 1890 & nd & $0.1 \pm 0.0^{\mathrm{a}}$ & nd \\
\hline C53 & E-Spiroether ${ }^{\mathrm{D}}$ & 1896 & $0.3 \pm 0.0^{\mathrm{a}}$ & $0.4 \pm 0.0^{\mathrm{b}}$ & $0.3 \pm 0.0^{\mathrm{a}}$ \\
\hline C54 & $\mathrm{NI}$ & 1920 & $0.1 \pm 0.0^{\mathrm{a}}$ & $0.1 \pm 0.0^{\mathrm{a}}$ & $0.1 \pm 0.0^{\mathrm{a}}$ \\
\hline C55 & Methyl hexadecanoate $\mathrm{O}$ & 1923 & $0.1 \pm 0.0^{\mathrm{a}}$ & nd & tr \\
\hline C56 & $\mathrm{NI}$ & 1944 & $0.7 \pm 0.0^{\mathrm{b}}$ & nd & $0.5 \pm 0.0^{\mathrm{a}}$ \\
\hline C57 & NI & 1949 & nd & $0.7 \pm 0.1^{\mathrm{a}}$ & nd \\
\hline C58 & NI & 2033 & nd & $\operatorname{tr}$ & $0.1 \pm 0.0^{a}$ \\
\hline C59 & 9,12-Octadecadienoic acid (Z,Z)-, methyl esterO & 2093 & $0.1 \pm 0.0^{\mathrm{a}}$ & nd & tr \\
\hline C60 & $9,12,15$-Octadecatrienoic acid, methyl ester ${ }^{\mathrm{O}}$ & 2099 & $0.1 \pm 0.0^{\mathrm{a}}$ & nd & $\operatorname{tr}$ \\
\hline C61 & PhytolOD & 2120 & $0.1 \pm 0.0^{\mathrm{a}}$ & nd & nd \\
\hline C62 & $\mathrm{NI}$ & 2141 & nd & $0.1 \pm 0.0^{\mathrm{a}}$ & nd \\
\hline C63 & Z,Z-9,12-Octadecadienoic acido & 2147 & $0.2 \pm 0.0^{\mathrm{b}}$ & nd & $0.1 \pm 0.0^{a}$ \\
\hline C64 & NI & 2152 & nd & $0.3 \pm 0.0^{\mathrm{a}}$ & nd \\
\hline C65 & Tricosane ${ }^{A}$ & 2298 & $0.2 \pm 0.0^{\mathrm{b}}$ & $0.1 \pm 0.0^{\mathrm{a}}$ & $0.1 \pm 0.0^{a}$ \\
\hline C66 & Tetracosane ${ }^{A}$ & 2394 & $0.1 \pm 0.0^{\mathrm{a}}$ & $\operatorname{tr}$ & tr \\
\hline C67 & Pentacosane ${ }^{A}$ & 2497 & $0.8 \pm 0.1^{\mathrm{c}}$ & $0.6 \pm 0.0^{\mathrm{b}}$ & $0.4 \pm 0.0^{\mathrm{a}}$ \\
\hline C68 & Heptacosane ${ }^{A}$ & 2694 & $0.2 \pm 0.0^{\mathrm{b}}$ & $0.1 \pm 0.0^{\mathrm{a}}$ & $0.1 \pm 0.0^{a}$ \\
\hline C69 & Nonacosane ${ }^{A}$ & 2895 & $0.1 \pm 0.0^{\mathrm{a}}$ & $\operatorname{tr}$ & tr \\
\hline & Monoterpene hydrocarbons (MT) & & 0.2 & 0.2 & 0.2 \\
\hline & Oxygenated monoterpenes (OMT) & & 0.2 & 0.1 & 0.1 \\
\hline & Sesquiterpene hydrocarbons (ST) & & 30.1 & 39.3 & 49.6 \\
\hline & Oxygenated sesquiterpenes (OST) & & 51.9 & 43.3 & 37.0 \\
\hline & Oxygenated diterpenes (OD) & & 0.1 & - & - \\
\hline & Others $(\mathrm{O})$ & & 1.7 & - & 0.1 \\
\hline & Diacetylenes (D) & & 12.1 & 12.7 & 9.6 \\
\hline & Alkanes (A) & & - & 0.8 & 0.6 \\
\hline & NI & & 2.0 & 3.5 & 2.3 \\
\hline & Total identified & & & 99.9 & 99.5 \\
\hline & Number of compounds & & 47 & 57 & 53 \\
\hline
\end{tabular}




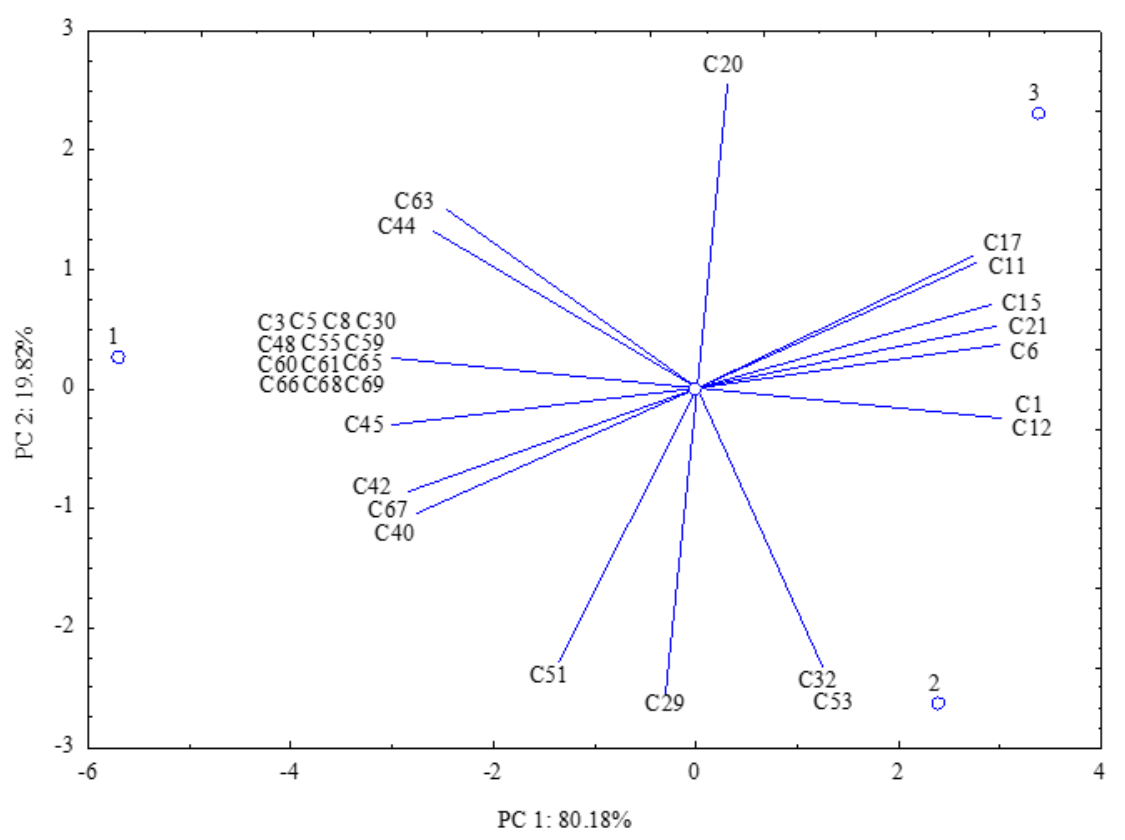

Figure 2. The PCA biplot diagram, showing the relationships among volatile compounds of different chamomile samples. The shown compound titles (C1-C69) were explained in Table 1.

the results were shown in the Figure 3. The darker the color of the squares, the stronger is the correlation between these compounds, i.e. likeness in the amounts of active compounds. At the same time, lighter color suggests a specific dissimilarity in active compounds content.

According to the analyzed results, the correlation among active C40-C69 compounds concentration found in Samples 1, 2 and 3 was mostly positive, while the correlation among C1-C32 compounds concentration was mainly negative. However, the correlation among tested samples for each individual compound was positive (Figure 3), which indicates that except the variation in the amounts of the major compounds, these compounds were still presented in similar rations when different processing methods were applied. Yet,

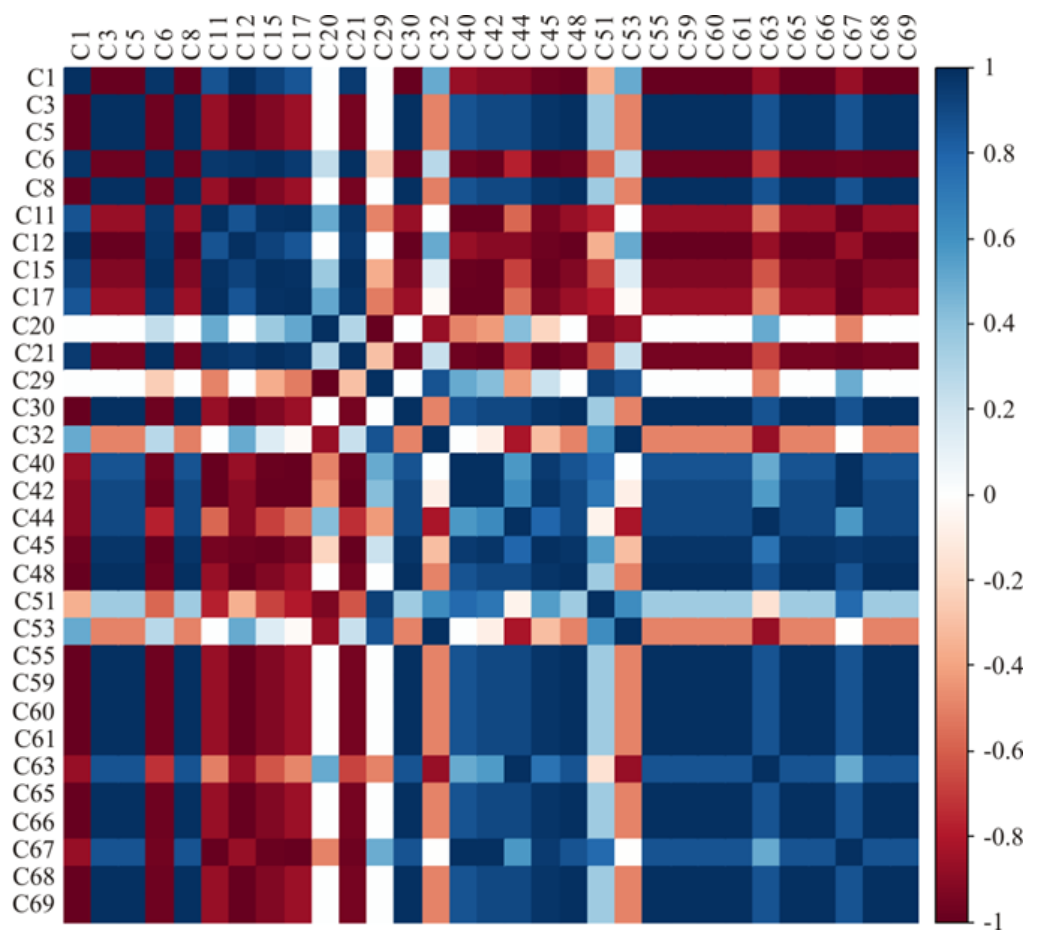

Figure 3. Correlation between volatile compounds of different Matricaria chamomilla samples. Colors blue and red indicate positive and negative correlation, respectively. A hue indicates the correlation among concentrations (positive or negative). 
according to statistical analysis (Table 1), that variation in the amounts of the individual constituents is statistically significant and points to a higher quality of the essential oil form the Sample 1, obtained from the first-class chamomile (flowers with short stems) material. Sample 1 essential oil contains the highest contents of $\alpha$-bisabolol, $\alpha$-bisabolol oxides $\mathrm{A}$ and $\mathrm{B}$, and chamazulene, which indicates the highest pharmacological value.

Essential oil yield and composition in chamomile are affected by genetic, agronomical and environmental factors (Kumar et al., 2020). In general, decreased duration of drying time leads to desired essential oil content and composition (Mahmoudi et al., 2020).

$\alpha$-Bisabolol is a naturally occurring oxygenated sesquiterpene alcohol, the most valuable compound from chamomile essential oil. However, the highest content of $\alpha$-Bisabolol is noted in ligulate flowers (Pekic et al. 1999). Oxygenated sesquiterpenes, such as $\alpha$-Bisabolol have higher boiling points compared to hydrocarbon sesquiterpenes, so this compound does not evaporate easily during manipulation of plant material process (Hazrati et al. 2021). This could explain the highest content of this compound in Sample 1 which mostly consists of chamomile flowers. $\alpha$-Bisabolol is used in a wide range of cosmetic formulations, as a skin conditioning agent, because of its anti-inflammatory and anti-allergic properties (Madhavan, 1999). However, it is also appreciated agents from naturally occurring dietary phytochemicals with gastro protective effects, antitumor activity and many others pharmacological properties (de Siqueira et al., 2014; Javed et al., 2020).

$\mathrm{E}-\beta$-farnesene is a common volatile component of chamomile and many higher plants (Satyal et al., 2015). Its biosynthesis originates from farnesyl diphosphate (FPP) via terpene synthases, and different levels of expression of terpene synthases influence accumulation (Block et al., 2017). Bearing in mind that highest content of E- $\beta$-farnesene was in the sample dried in a bulk, immediately after harvest, without further cleaning, the accumulation of this compound could be a consequence of high activity of terpene synthases during fermentation, due to high respiration rate (Tippmann et al., 2016). This compound is a pheromone in several insect species could have importance in ecological pest control.

Spiroethers from chamomile are important due to their unique biological activity profiles. In this study, the highest content of $Z$-spiroether is noted in sample of chamomile flowers with long stems and leaves. It is known that the leaves have the highest concentration of spiroether (Ma et al. 2007), as well as that spiroether content increases during drying process (Abbas et al., 2021). Of the two spiroether isomers, the cis form exhibits more potent activity (Ma et al., 2007), such as high antimicrobial activity (Kazemi, 2015), and also completely inhibits the production aflatoxin G1 (AFG1) by Aspergillus parasiticus and 3-acetyldeoxynivalenol (3ADON) by Fusarium graminearum (Yoshinari et al., 2008).

\section{Conclusions}

Considering that essential oil obtained from the firstclass chamomile (flowers with short stems) contain the $\alpha$ -Bisabolol as the main compound, its pharmacological value is the highest in comparison to other two samples. Essential oil from chamomile sample with long stems has high content of $Z$-spiroether, while essential oil obtained from chamomile plant material without separation has high content E- $\beta$-farnesene. All these results indicate the importance of precise and controlled postharvest treatments, since it clearly affects the essential oil quality and content in the primary processing of this valuable medicinal plant.

\section{References}

Abbas, A.M., Seddik, M.A., Gahory, A.A., Salaheldin, S., Soliman, W.S. (2021). Differences in the aroma profile of chamomile (Matricaria chamomilla L.) after different drying conditions. Sustainability, 13, 5083. DOI: $10.3390 /$ su13095083

Acimovic, M., Stankovic, J., Cvetkovic, M., Kiprovski, B., Todosijević, M. (2018). Essential oil quality of tetraploid chamomile cultivars grown in Serbia. Journal of Essential Oil Bearing Plants, 21, 15-22; DOI: 10.1080/0972060X.2017.1401962

Acimovic M., Stankovic Jeremic J., Simic K., Ivanovic S., Ljujic J., Cabarkapa I., Radojcin M., Todosijevic M., Cvekovic M. (2021): Essential oil quality of chamomile grown in Province of Vojvodina. Letopis Naućnih Radova, 45, 63-70.

Arslan D., Bayraktar Ö.V., Temel M., Bayram E. (2019). Economical analysis of chamomile (Matricaria recutita L.) cultivars, flower yields which are obtained from different sowing times and row spacing. Journal of Agricultural Sciences, 25, 129-136.

Block, A., Vaughan, M.M., Christensen, S.A., Alborn, H.T., Tumlinson, J.H. (2017). Elevated carbon dioxide reduces emission of herbivoreinduced volatiles in Zea mays. Plant, Cell and Environment, 40, 17251734. DOI: $10.1111 /$ pce. 12976

Bottcher, H., Gunther, I., Franke, R., Warnstorff, K. (2001). Physiological postharvest responses of Matricaria (Matricaria recutita L.) flowers. Postharvest Biology and Technology, 22, 39-51; DOI: 10.1016/S09255214(00)00178-2

Bucko, D., Salamon, I. (2007). The essential oil quality of chamomile, Matricaria recutita L., after its large-scale distillation. Acta Horticulturae 749, 269-273; DOI: 10.17660/ActaHortic.2007.749.34

Das, M. (2014). Chamomile: Medicinal, Biochemical, and Agricultural Aspects. CRC Press.

de Siqueira, R.J.B., Ribeiro-Filho, H.V., Freire, R.S., Cosker, F., Freire, W.B.S., Vasconcelos-Silva, A.A., Soares, M.A., Lahlou, S., Magalhães, P.J.C. (2014). (-)- $\alpha$-Bisabolol inhibits preferentially electromechanical coupling on rat isolated arteries. Vascular Pharmacology, 63, 37-45; DOI: 10.1016/j.vph.2014.06.006

Ghasemi, M., Modarresi, M., Jelodar, N.B., Bagheri, N., Jamali, A. (2016). The evaluation of exogenous application of salicylic acid on physiological characteristics, proline and essential oil content of chamomile (Matricaria chamomila L.) under normal and heat stress conditions. Agriculture, 6, 31; DOI: 10.3390/agriculture6030031

Gosztola, B., Sárosi, S., Németh, É. (2010). Variability of the essential oil content and composition of chamomile (Matricaria recutita L.) affected by weather conditions. Natural Product Communications, 5(3), 465-470; DOI: 10.1177/1934578X1000500325

Hazrati S., Lotfi K., Govahi M., Ebadi M.T. (2021). A comparative study: Influence of various drying methods on essential oil components and biological properties of Stachys lavandulifolia. Food Science and Nutrition, 9(5), 2612-2619.

Javed, H., Meeran, M.F.N., Azimullah, S., Eddin, L.B., Dwivedi, V.D., Jha, N.K., Ojha, S. (2020). $\alpha$-Bisabolol, a dietary bioactive 
phytochemical attenuates dopaminergic neurodegeneration through modulation of oxidative stress, neuroinflammation and apoptosis in rotenone-induced rat model of Parkinson's disease. Biomolecules, 10, 1421; DOI: 10.3390/biom10101421

Karkanis, A., Lykas, C., Liava, V., Bezou, A., Petropoulos, S., Tsiropoulos, N. (2018). Weed interference with peppermint (Mentha $\times$ piperita L.) and spearmint (Mentha spicata L.) crops under different herbicide treatments: effects on biomass and essential oil yield. Journal of the Science of Food and Agriculture, 98(1), 43-50; DOI: 10.1002/jsfa.8435

Kazemi, M. (2015). Chemical composition and antimicrobial activity of essential oil of Matricaria recutita. International Journal of Food Properties, 18, 1784-1792; DOI: 10.1080/10942912.2014.939660

Kumar, D., Suryavanshi, P., Padalia, R.C., Chauhan, A., Venkatesha, K.T., Tiwari, A.K., Singh, V.R., Singh, S, Upadhyay, R.K. (2020). Evaluation of harvesting time and standardization of distillation duration for higher essential oil content and quality in German chamomile (Chamomilla recutita L.). Journal of Spices and Aromatic Crops, 29(2), 140-147; DOI: 10.25081/JOSAC.2020.V29.I2.6452

Letchamo, W. (1996). Developmental and seasonal variations in flavonoids of diploid and tetraploid chamomile liqulate florets. Journal of Plant Physiology, 148(6), 645-651; DOI: 10.1016/S0176-1617(96) 80361-0

Ma C.M., Winsor L., Daneshtalab M. (2007). Quantification of spiroether isomers and herniarin of different parts of Matricaria matricarioides and flowers of Chamaemelum nobile. Phytochemical Analysis, 18, 42-49.

Madhavan, B.N. (1999). Final report on the safety assessment of bisabolol. International Journal of Toxicology, 18(3), 33-40. DOI: $10.1177 / 109158189901800305$.

Mahmoudi A., Karami M., Ebadi M.T., Ayyari M. (2020). Effects of infrared drying and air flow rate on qualitative parameters of Matricaria chamomilla L. Iranian Journal of Medicinal and Aromatic Plants Research, 36(5), 723-737. DOI: 10.22092/ijmapr.2020.341490.2701

Oztekin, S., Martinov, M. (2007). Medicinal and aromatic crops, harvesting, drying and processing. Haworth Foods and Agriculture Product Press, New York.
Pekic B., Zekovic Z., Petrovic L. (1999). Essential oil of chamomile ligulate and tubular flowers. Journal of Essential Oil Research, 11, 16-18.

Ph. Eur. 8.0. (2013). European Pharmacopoeia 8.0. Method 2.8.12. Volume 1. Strasbourg Council of Europe: Strasbourg, France.

Sarkic, A., Stappen, I. (2018). Essential oils and their single compounds in cosmetics - a critical review. Cosmetics, 5, 11; DOI: 10.3390/ cosmetics5010011

Satyal, P., Shrestha, S., Setzer, W.N. (2015). Composition and bioactivities of an (E)-B-farnesene chemotype of chamomile (Matricaria chamomilla) essential oil from Nepal. Natural Product Communications, 10(8), 1453-1457; DOI: 10.1177/1934578X1501000835

Statistica 10 Software (StatSoft, Inc. STATISTICA, ver. 10, Data Analysis Software System). Available online: https://www.statsoft.de/en/ home (accessed on 15 December 2018).

Szabo, K., Nemeth, E., Sarosi, Sz., Czirbus, Z. (2010). Essential oil content of Hungarian wild chamomile (Chamomilla recutita L.) and its composition during primary processing - survey of practice. Forum, 15(2), 63-68; DOI: 10.4103/0973-7847.79103

Tippmann, S., Scalcinati, G., Siewers, V., Nielsen, J. (2016). Production of Farnesene and Santalene by Saccharomyces cerevisiae Using FedBatch Cultivations With RQ-Controlled Feed. Biotechnology and Bioengineering, 113 (1), 72-81. DOI: 10.1002/bit.25683.

Upadhyay, R.K., Singh, V.R., Tewari, S.K. (2016). New agro-technology to increase productivity of chamomile (Matricaria chamomilla L.). Industrial Crops and Products, 89, 10-13; DOI: 10.1016/ j.indcrop.2016.04.072.

Yoshinari, T., Yaguchi, A., Takahashi-Ando, N., Kimura, M., Takahashi, H., Nakajima, T., Sugita-Konishi, Y., Nagasawa, H., Sakuda, S. (2008). Spiroethers of German chamomile inhibit production of afatoxin G1 and trichothecene mycotoxin by inhibiting cytochrome P450 monooxygenases involved in their biosynthesis. FEMS Microbiology Letters, 284(2), 184-190; DOI: 10.1111/j.15746968.2008.01195.x

Zadeh, J.B., Kor, N.M., Kor, Z.M. (2014). Chamomile (Matricaria recutita) as a valuable medicinal plant. International Journal of Advanced Biological and Biomedical Research, 2(3), 823-829.

\section{Uticaj tretmana posležetvene separacije na kvalitet etarskog ulja kamilice}

\section{Milica Aćimović · Biljana Lončar · Biljana Kiprovski · Jovana Stanković Jeremić · Marina Todosijević · Lato Pezo · Jelena Jeremić}

Sažetak: Ekološki uslovi proizvodnog područja, tehnologija gajenja kao i žetva, ali i posležetveni tretmani značajno utiču na prinos i kvalitet kamilice. Cilj ovog istraživanja je bio da se odredi uticaj metoda separacije, kao posležetvenog tretmana, na kvalitet etarskog ulja, sa ciljem da se unapredi process primarne prerade ove lekovite biljke. Da bi se objasnila struktura laboratorijskih podataka, procenile i sagledale sličnosti i razlike između uzoraka etarskih ulja kamilice dobijenih primenom različitih metoda separacije, korišćena je PCA metoda. Dobijeni rezultati pokazuju da separacija sirovine kamilice kao posležetveni tretman koji prethodi sušenju, ima značajnog uticaja na broj identifikovanih komponenti u etarskom ulju, ali i njihov udeo. Najmanji broj pojedinačnih komponenti u etarskom ulju je imao uzorak cvetnih glavica sa kratkom drškom, pri čemu je zabeležen najveći sadržaj $a$-bisabolol, hamazulen, $Z$-spiroeter i $E$ - $\beta$-farnesen. U etarskom ulju dobijenom od biljne sirovine sa većim udelom stabla kamilice, sadržaj $a$-bisabolola i hamazulena je bio značajno niži, dok je sadržaj $E$ - $\beta$-farnesena i $Z$-spiroetera bio značajno viši. Dalje, u etarskom ulju dobijenom od bioljnog materijala bez separacije, zabeležen je najniži sadržaj $a$ bisabolola i $Z$-spiroetera, i najveći sadržaj $E$ - $\beta$-farnesena. Analiza korelacije je izvedena da bi se ispitala sličnost u sadržaju aktivnih komponenti u etarskom ulju dobijenom primenom različitih procesa separacije kamilice. Svi rezultati ukazuju na značaj primene posležetvenih tretmana, jer se jasno vidi njihov uticaj na kvalitet etarskog ulja ove veoma važne lekovite bilike.

Ključne reči: etarsko ulje, lekovito bilje, Matricaria chamomilla, posležetvena prerada, primarna prerada, separacija

This article is distributed under the terms of the Creative Commons Attribution 4.0 International License (http://creativecommons.org/licenses/by/4.0), which permits unrestricted use, distribution and reproduction in any medium, provided you give appropriate credit to the original author(s) and the source, provide a link to the Creative Commons license, and indicate if changes were made. 